\title{
Leibniz's Early Theodicy and its Unwelcome Implications
}

Thomas Feeney

Abstract: To explain why God is not the author of sin, despite grounding all features of the world, the early Leibniz marginalized the divine will and defined existence as harmony. These moves support each other. It is easier to nearly eliminate the divine will from creation if existence itself is something wholly intelligible, and easier to identify existence with an internal feature of the possibles if the divine will is not responsible for creation. Both moves, however, commit Leibniz to a necessitarianism that is stronger than what prominent interpreters such as Robert Sleigh and Mogens Lærke have found in the early Leibniz, and stronger than the necessitarianism that threatens his later philosophy. I defend this reading of Leibniz and propose that some features of Leibniz's later metaphysics, including his "striving possibles" doctrine, are an artifact of the effort to rescue the early theodicy from its unwelcome implications.

Thirteen years after leaving Paris, Leibniz recalled his youth: he had come "very close to the view of those who think that everything is absolutely necessary" (FC $178=$ AG 94. See also G VI, $217=\mathrm{H}$ 173). ${ }^{1}$ As he tells it, the Principle of Sufficient Reason (PSR) made necessitarianism appealing, the conceivability of non-existent possibles made it unappealing again, and then

${ }^{1}$ I use these additional abbreviations: $\mathrm{CP}=$ Confessio philosophi (2005); $\mathrm{DSR}=$ De summa rerum (1992); M = Leibniz: Monadology and other Philosophical Essays (1985); MP = Leibniz: Philosophical Writings (1973); P = Logical Papers (1966); SLT = The Shorter Leibniz Texts (2006); VE = Advance copy of A VI.v (2018). Translations are cited after an equal sign. 
fortunately, several metaphysical insights broke the connection between the PSR and necessity. ${ }^{2}$ This version of the story has become a template for present-day interpreters, ${ }^{3}$ but it omits the theodicean roots of Leibniz's early necessitarianism, and so fails to recognize Leibniz's struggle at the end of his Paris Period to rescue his theodicy from the metaphysics he had developed to support it.

Leibniz's Paris Period (1672-6) commitment to necessitarianism may have been reluctant or even unwitting, but it was rooted in more than just the PSR. His early attempt at theodicy in the Confessio philosophi (1672/3) turned on a restriction of the divine will. His metaphysical speculations in the De summa rerum (1675-6) supported this theodicy by making harmony the defining feature of existence itself, not the feature that gives God a reason to will that certain things exist. Both moves imply strong necessitarianism, that is, an ineluctablenearly Spinozistic — necessitarianism that cannot be made to appear less like necessitarianism by means of a distinction between per se and merely hypothetical necessity.

${ }^{2}$ The PSR states that nothing exists (A VI.iii, $118=$ CP 35), happens (FC $178=$ AG 94), or holds true (A VI.iv, $1650=$ AG 28) without a sufficient reason. Necessitarianism is the view that nothing could have been different.

${ }^{3}$ See, for example, Lin 2011, 421: "Like Spinoza, Leibniz is a metaphysical rationalist. And at one stage early in his career, Leibniz was also a necessitarian. But in contrast to his unwavering commitment to the PSR, Leibniz's commitment to necessitarianism was fleeting. He was aware of the argument from rationalism to necessitarianism. But instead of giving up rationalism, he sought to block the inference to necessitarianism.” See also Adams 1977; Cover \& Hawthorne 1999, 93; Strickland 2006, 7-11; Levey 2013, 171-175; and Newlands 2013, 156-157. Adams may be the original source; Newlands references the narrative without endorsing it. 
But that is the distinction Leibniz used in the years immediately following his departure from Paris in 1676 to counter the argument from the PSR to necessitarianism. ${ }^{4}$ He must have done something more, around 1676/7, to disentangle himself from strong necessitarianism. In fact he did, by simultaneously restoring the active power of the divine will and abandoning the effort to define existence. Still, he did not simply abandon his early theodicy. Leibniz's postParis metaphysics is a carefully calibrated attempt to transfer some of the intellect's role to the divine will and thereby strengthen the distinction between God's mind and creation —all without making God the author of sin.

In defending this interpretation, I part ways more subtly with Robert Sleigh, Mogens Lærke, and Paul Rateau, whose careful interpretations and textual analysis provide the point of departure for work on Leibniz's early encounter with necessitarianism. Robert Sleigh (1996, 492; CP xxxv) twice sketches and dismisses an interpretation of the early theodicy in the Confessio philosophi that commits Leibniz to a broadly Spinozistic necessitarianism. On the interpretation Sleigh favors, Leibniz came close to necessitarianism only in the sense that he lacked the words to adequately explain his true position, based on the distinction between per se and merely hypothetical necessity, without dangerous ambiguities. ${ }^{5}$

Unlike Sleigh, Mogens Lærke (2007, 8 \& 20-1; 2008a, 380-381, 547-551, and 795796) endorses a necessitarian reading of the Confessio philosophi and finds more evidence of the same in the De summa rerum, the collection of Paris Period metaphysical papers. On Lærke's view, necessitarianism sprang from ontological poverty - the early Leibniz thought that nonexistent possibles were mere logical abstractions, without an ontological foothold. If possibles

${ }^{4}$ This distinction appears first in Leibniz's 1677/8 revisions to the Confessio philosophi and in some accompanying texts (CP 57-9, $119 \& 123-5)$.

${ }^{5}$ Griffin (2013, 63-66) agrees that the main developments were terminological, and that Leibniz maintained roughly the same position during and after his Paris Period. Unlike Sleigh, however, Griffin finds an enduring necessitarianism. 
are mere abstractions and not options present eternally in the divine intellect, then there is no reason to say that there are any mere possibiles. Nachtomy (2008) replied to Lærke, finding a more robust ontology of possibles in the early Leibniz, and Lærke (2008b) then replied to Nachtomy, defending his own reading. My argument is orthogonal to this exchange, because I hold that Leibniz's commitment to strong necessitarianism remains even if Nachtomy is rightontological poverty could not be its source.

Rather, Leibniz's commitment to strong necessitarianism was a consequence of the central tenet of his early theodicy, that the divine will is not causally effective in creation. Moreover, Leibniz supported his theodicy with a metaphysics, in particular a definition of existence as harmoniousness, and that too implied necessitarianism. Leibniz's best effort at theodicy pulled him, perhaps unawares and probably against his own intentions, toward a metaphysics with no room for non-existent possibles. Pulling back required a new theodicy and a new metaphysics: it was not enough to state the distinction between hypothetical and per se necessity explicitly (as Sleigh maintains), and not enough to explain that existent and nonexistent possibles alike are objects of the divine understanding (as Lærke maintains).

Here I am in broad agreement with Paul Rateau (2014, 173; see also 2019, 72), who writes that "[i]t is only by reconsidering the role of the divine will and in deepening the notion of the possible that we will break out of strict necessitarianism [...]" (my translation). We disagree, however, because he reads the weak account of the will as a consequence of an already established necessitarianism, based on Leibniz's appeal to the PSR in the Confessio philosophi (2019, 58-65), without drawing the connection to Leibniz's effort to define existence in the $D e$ summa rerum. For Rateau, Leibniz deepens his notion of the possible precisely by strengthening his notion of the will, thereby rendering every coherent series of possibles a genuine contender for God's choice $(2019,89-107 \& 120)$.

I also defend a deeper continuity, which appears once we notice the full extent of this discontinuity in Leibniz's metaphysics and theodicy. Leibniz's rapid development after leaving Paris in late 1676 appears most clearly as an effort to preserve as much as possible of his early 
theodicy while avoiding its unexpected and unacceptable consequences. For example, as Rateau $(2019,94-107)$ argues, the claim that possibles strive for existence in proportion to their degree of perfection (or harmony) matches Leibniz's more robust notion of the will, as an arbiter among possibles, but leaves the ultimate explanation for this world's existence to the divine understanding. Rateau does not go far enough, however, because associating harmony with the propensity to exist is a close descendant of the attempt to define existence itself in terms of harmony. The early definition of existence precludes any creative act of will, while its successor - the "striving possibles" doctrine - grants the will a significant but carefully delimited role. These deeper continuities, which Rateau describes in part, are not available to Lærke and Sleigh, or to any other interpreter who misses the full extent to which Leibniz's early theodicy committed him to necessitarianism. ${ }^{6}$

The paper has three sections. In the first, I present the necessitarian interpretation of the Confessio philosophi and raise a concern that Leibniz seems to have taken seriously: the early theodicy undermines the distinction between existent and non-existent possibles. The second section finds an answer to that concern in Leibniz's metaphysical papers from the same period, but unfortunately the answer turns out to deepen Leibniz's commitment to strong necessitarianism. The final section shows how Leibniz, just after his encounters with Spinoza in writing and in person, granted the divine will a productive and explanatory role, enough to distinguish a contingent (or at least only hypothetically necessary) world from its per se necessary creator, but not enough to make the will itself responsible for sin.

\section{Creation Without God's Will: the Confessio philosophi}

${ }^{6}$ Ohad Nachtomy $(2008,255)$ and Christia Mercer (2001, 386-8) find more continuity between the early and late Leibniz than Sleigh and Lærke find, and so find even less evidence of an escape from Spinozistic necessitarianism. On whether the encounter with Spinoza marks a discontinuity, see Goldenbaum 2007. 
The Confessio philosophi relieves God of moral responsibility for sin by drastically reducing the role of God's will in creation; the divine intellect is responsible not only for the logical space of possibilities, but also for the actuality of the existent possibles. What follows from the divine intellect follows necessarily, and so this theodicy implies necessitarianism. Moreover, this is strong necessitarianism, because what follows from the divine intellect participates in God's own per se necessity.

I defend this interpretation in two steps. First, following the text closely, I introduce the necessitarian concern that Leibniz raises explicitly, that Sleigh and Lærke also notice, and that may be addressed with an expanded modal vocabulary (Sleigh) or an expanded ontology of possibles (Lærke). Second, pressing that concern further, I argue that Leibniz cannot avoid a stronger form of necessitarianism, with consequences for his metaphysics of creation and of existence: if nothing owes its existence to God's will, and all possibles — existent or not —are in God's intellect, then nothing seems to change when God creates.

\subsection{Necessitarianism (Round One)}

This early Paris Period dialogue presents the "Author of Sin" problem as the central theodicean issue: God seems to take on moral responsibility for sin by creating a world in which there is so much of it. There are two speakers, a philosopher and a theologian. The dialogue takes up just after the philosopher has completed a PSR-based argument for the existence of God.

The theologian worries that this principle, so useful for proving God's existence, will make the Author of Sin problem insoluble. He forces the philosopher to follow the chain of reasons from sin back to God. As the theologian worries, "The ultimate ground [ratio] for sin, like everything else, and hence even for damnation, is God" (A VI.iii, 121 = CP 39). This leaves the philosopher out of breath, and the characters wait until suddenly the philosopher announces that the darkness has been "split as by some unexpected stroke of light" (A VI.iii, 121 = CP 41). 
Leibniz's language is dramatic: the philosopher suddenly becomes "cheerful" and his face promises "something joyful and exciting." My interpretation should rest on Leibniz's arguments. Nevertheless, the drama is evidence that the philosopher, and so Leibniz himself, is not merely rehearsing familiar moves. Leibniz primes the reader to expect the unexpected.

The stroke of light is a new distinction between what originates from the divine intellect and what originates from the divine will. God is the ground of the former, but the author only of the latter. ${ }^{7}$ For example, God does not cause mathematical truths to be true by willing them; rather, they are true simply because God understands them, and God understands them simply because God exists (A VI.iii, $122=\mathrm{CP} 43$ ). Not surprisingly, the philosopher argues that God is the ground of sin through the divine intellect, but in no way wills that there be sin. "Sins," he explains, "are not due to the divine will but rather to the divine understanding or, what is the same, to the eternal ideas or the nature of things" (A VI.iii, $121=\mathrm{CP} 41$ ).

The philosopher then delivers the unexpected move. He assimilates the existence of sin to the family of truths that depend directly on the divine intellect. That sin exists is not a mathematical truth, but it is a truth about harmony and discord. Considered in isolation, sins are discordances, but considered as parts of "the entire series of things," sins contribute to harmony

${ }^{7}$ As the philosopher later explains, "to be the author is by one's will to be the ground of something else" (A VI.iii, 127 = CP 55). He does not offer a similar definition of "ground," but slightly further on the philosopher does recommend substituting "ground" for "cause" in sentences such as "God is the cause of sin." He commends the substitution for rhetorical reasons; the original sentence would stir up too much controversy (A VI.iii, $126=$ CP 51-3). This, together with the common philosophical use of "ratio" to mean "explanation, account," suggests that being the ground of $X$ involves causing $X$ to be and making the existence of $X$ intelligible. 
(A VI.iii, 123 = CP 45). That harmony, and sin with it, is just as little an effect of God's will as the sort of harmony that mathematicians study. ${ }^{8}$

The theologian summarizes the philosopher's conclusion, and broadens it to include all created beings:

the universal harmony is a result not of the will of God but the intellect of God, or of the ideas, that is, the nature of things. Therefore sins are to be ascribed to the same thing; accordingly, sins follow from the existence of God, not the will of God. (A VI.iii, $122=$ CP 45)

The philosopher agrees, and appeals again to the PSR. The whole series of existents requires a sufficient reason, to be found in God. But, if it were possible for a different series to follow from God, then God would not be the sufficient reason for the actual series. So it must be that finite existents follow from the existence of God necessarily, and indeed (though Leibniz's character does not and would not say this) that God is not the author of anything (A VI.iii, 123-4 = CP 47). ${ }^{9}$

${ }^{8}$ Leibniz expressed something closer to his mature view just one year earlier: "For God wills those things that he perceives to be the best and, likewise, the most harmonious; and he selects them, so to speak, from the infinite number of all the possibles" (Letter to Wedderkopf, 1671; A II.i, $117=$ CP 2-3). Perhaps this represents Leibniz's actual view in the period and the Confessio philosophi does not. More likely, as Sleigh (CP xxxii) suggests, Leibniz was dissatisfied with his theodician notes to Wedderkopf, because they failed to explain why God is not the author of sin. ${ }^{9}$ Rateau $(2019,65)$ highlights this apparent consequence: "It would seem that all things, and not merely sins, must be referred not to God's will, but to his nature - that is, to the universal harmony (as the theologian in the dialogue observes). This seems to license the characterization 
The dialogue so far seems unquestionably necessitarian: we have this argument from the PSR to necessitarianism as well as the unexpected move that makes the existence of finite things follow directly from the existence of God. The theologian raises these concerns (A VI.iii, $125 \&$ $127=\mathrm{CP} 49 \& 55)$ and the philosopher answers that sin does not exist necessarily, because other ways for the world to be are conceivable and hence possible. For example, some fictional characters could have been actual (A VI.iii, 128-9 = CP 57-9). Also, the penalty for excluding non-existent possibles would be too steep:

Those who think otherwise necessarily destroy the difference between truth and possibility, necessity and contingency, and, having twisted the meaning of the words, they oppose themselves to the ordinary use of words. Therefore sins, damnations, and the other elements of the series of contingent things are not necessary, even if they follow from something necessary - the existence of God or the harmony of things. (A VI.iii, $129=$ CP 59)

In one sense, this is decisive evidence against a necessitarian reading of the Confessio philosophi: necessitarianism was surely not Leibniz's intent. This is also evidence that the distinction between per se and hypothetical necessity was Leibniz's solution to the necessitarian

of God as lacking a will and to make of him a mere physical rather than moral cause." Considering Leibniz's even earlier work (1663-1670), André Robinet (1994, 3-12) also finds traces of the claim that God is a mere physical cause and not a moral cause. Here, Robinet sees a Hobbesian voluntarism in which God gives the moral law without being bound by it. Rateau (2019, 23-28) argues convincingly that these early traces do not indicate voluntarism, but rather an openness to the sort of necessitarianism we find in the Confessio philosophi. 
implications of his early theodicy, as in Sleigh's interpretation, which finds the distinction latent in passages like this, but explicit only later in the post-Paris 1678 notes and revisions. ${ }^{10}$

In the passage just quoted, Leibniz claims that something may follow from something necessary, and yet fail to be necessary. On the assumption that "follows from" is a relation holding necessarily between its relata, this violates what is now considered the most basic axiom of modal logic: $(\alpha \wedge \quad(\alpha \rightarrow \beta)) \rightarrow \quad \beta$. Later, after leaving Paris, Leibniz emended the manuscript to include the distinction between per se and hypothetical necessity, which he used to explain just how the seemingly unobjectionable modal axiom equivocates between two senses of "necessarily." Something may follow necessarily from something necessary and yet not be necessary, because its existence does not follow from its own nature [per se] but rather from something else [ex alterius hypothesi], thereby leaving its nonexistence still possible in itself [per se contingentia] (A VI.iii, 127-8 = CP 55-7).

In the earlier version, however, Leibniz was already prepared to say that anyone who employs this modal axiom opposes “the ordinary sense of words.” Leibniz's complaint suggests that Sleigh is right: a full escape from necessitarianism demanded new modal terminology.

\subsection{Necessitarianism (Round Two)}

So, Leibniz did not intend to accept necessitarianism, and he did eventually develop new modal terms to block the PSR-based argument to necessitarianism. Commitment, though, does not require intent, as we learn from the questions after a philosophy talk. A speaker is committed to $p$ if her premises imply $p$ - even if she argues against $p$ and rejects $p$ explicitly. Indeed, Leibniz's

${ }^{10}$ On these dates and on the division between the $1672 / 3$ original and the later revisions, see Robert Sleigh's introduction to the Yale Leibniz edition of the Confessio philosophi (CP xxixxiii). 
character, the theologian, attempts to show that the philosopher is committed to necessitarianism in just this sense of commitment:

What is your response going to be to the argument proposed previously: the existence of God is necessary; the sins included in the series of things follow from this; whatever follows from something necessary is itself necessary. Therefore sins are necessary. (A VI.iii, $127=$ CP 55)

Pressing the theologian's objection further than he does in the Confessio philosophi, I argue that Leibniz's heavily intellectualist theodicy would still have committed him to necessitarianism, even if he had had the distinction between per se and hypothetical necessity fully at his disposal in $1672 / 3 .{ }^{11}$

If this distinction helps with the necessitarian objection at all, it does so by allowing for the contingency of beings that are really distinct from their necessitating and necessarily existing ground, that is, beings that can be conceived per se, or independently of that ground. ${ }^{12}$ However, the finite things in Leibniz's early theodicy seem to be no more than divine ideas (or the contents of divine ideas), not creations with a being distinct from God's own being. Leibniz's later work

${ }^{11} \mathrm{He}$ at least had the conceptual resources. For a 1667-69 distinction between absolute and relative impossibility, see A VI.i, 398.

${ }^{12} \mathrm{~A}$ is really distinct from $\mathrm{B}$ if and only if $\mathrm{A}$ can be conceived without B. Leibniz argues in two early 1676 letters to Malebranche (A II.i, 399-401 \& 403-406) that real distinction does not imply separability. He needs this, because a per se contingent but hypothetically necessary being is really distinct from but not separable from its ground. The concern here, though, is that divine ideas or possibles are not even really distinct from God. For a helpful discussion on real distinction and separability, see Lærke 2009b; for an account of the role that ways of conceiving play in per se modality, see Newlands 2010,83-96. 
on per se and hypothetical necessity cannot gain the foothold it needs to pry the early theodicy apart from necessitarianism so long as Leibniz has not yet pried the candidates for merely hypothetical necessity apart from their per se necessary source.

To defend this objection, I should argue (i) that divine ideas are not really distinct from God, and (ii) that the "created" beings in Leibniz's early theodicy can be no more than divine ideas. First, divine ideas are not really distinct from God, at least not in the robust sense needed to deploy the distinction between per se and hypothetical necessity, because conceiving of a divine idea without God's intellect is much harder than conceiving of a created being without its creator. For Leibniz, creaturely dependence on the creator comes in layers: creation itself, conservation, and concurrence. Nevertheless, part of the point of creation is that creatures have some measure of conceptual and ontological independence; being created ex nihilo implies a radical dependence on the creator, but also implies existence apart from the God who does not come to be at all (see McDonough 2007). On the other hand, God's ideas exist just if God exists, and their being just is God's being; otherwise, they too would be creatures formed ex nihilo. ${ }^{13}$

Second, the "created" beings in Leibniz's early theodicy can be no more than divine ideas or the contents of divine ideas, because Leibniz's early theodicy cannot appeal to an act of

${ }^{13}$ Recall here Leibniz's own words: "to the divine understanding or, what is the same, to the eternal ideas or the nature of things" (A VI.iii, $121=\mathrm{CP} 41$ ). An anonymous reviewer suggested that the content of a divine idea might be really distinct from God, because God can conceive of that content without conceiving of God, even if the idea itself is not really distinct from God. On this view, the idea of Adam is not a candidate for per se contingency, but the content of this idea is. But what is this content if not a feature of God's intellect? It cannot be Adam himself, because Leibniz's intellectualist account of creation supplies no basis for a distinction between Adam and the idea of Adam. It could be the essence or concept of Adam, but plausibly this just is the divine idea. For a dispute about whether essences are best seen as the intentional content of divine ideas or as identical to those ideas, see Nachtomy 2007, 14-16; Newlands 2013, 165n26. 
the divine will that makes some possible things exist and leaves others as merely conceivable or possible. They all have their being in the way that mathematical truths have theirs, as ideas (A VI.iii, $123=\mathrm{CP} 45)$. Admittedly, Leibniz does write that "the sins included in this total series of things are due to the ideas themselves of things, i.e., to the existence of God. In positing this, they are posited; this being taken away, so are they" (A VI.iii, $124=$ CP 47). He still claims that sins are "due to" the ideas, but forgoes any appeal to the will that could make the difference between a conception in God's intellect and an existence ex nihilo. ${ }^{14}$

With no creation event, existent and non-existent possibles alike are grounded in God's intellect as ideas in a mind. So, they are not really distinct from God and thereby share in God's own per se necessity, not the merely hypothetical necessity of genuinely created entities. That is Leibniz's (perhaps unintended) commitment to strong necessitarianism in his early theodicy.

Sleigh $(1996,492)$ considers this interpretation of the Confessio philosophi "not altogether implausible," but rejects it because it makes Leibniz's early theodicy "too close to the views of the dreaded Spinoza" and too far from Leibniz's more definitively expressed later views. Taken separately, these are two reasons to reject my interpretation of the Confessio philosophi. Without a compelling narrative explanation, it would indeed be charitable to find continuity in Leibniz's thought whenever possible. Taken together, however, Sleigh's two

14 This interpretation is strengthened by contrast with Leibniz's more mature statements. In a 1677/8 marginal note, Leibniz corrected the previous quote: "The series is not posited because God is posited, except for the fact that God, who is the most wise being, wills nothing but the best. All possible series are in the idea of God, but only one under the aspect of the best" (A VI.iii, $124=$ CP 47). Here, the divine will does something with the best of God's ideas; finite things no longer follow directly from God's existence. These changes remain in place to the end of Leibniz career: "Actual beings depend upon God for their existence as well as for their actions, and depend not only upon his intellect but also upon his will" (Causa Dei, 1710; G VI, $440=$ M 115) 
reasons to reject my interpretation form just such a narrative: exposure to Spinoza helped Leibniz to understand the full extent of his own commitments, and thereby motivated him to develop a theodicy in which merely hypothetical necessity can find a foothold.

\section{Metaphysically Entrenched Necessitarianism: the De summa rerum}

So far I have concentrated on Leibniz's Paris-period theodicy and its immediate metaphysical consequences. During the same period, though, Leibniz produced extensive metaphysical speculations collected together in the De summa rerum (December 1675-December 1676), the primary collection of metaphysical works from this period. Here I find a metaphysics that supports the theodicy. Exploring that metaphysics shows that Leibniz was deeply entrenched in a necessitarian position: his effort to define existence provides another, even more direct, path to strong necessitarianism.

\subsection{Defining Existence}

Leibniz's early theodicy gave him two options. He could have denied a distinction between the existent and the non-existent possibles, thereby immediately accepting necessitarianism, or he could have offered a principled distinction between the existent and the non-existent possibles, a distinction compatible with all possibles being objects of the divine intellect. ${ }^{15}$

${ }^{15}$ Lærke $(2007,7-8)$ sees this problem and attempts to preserve the distinction between nonexistent and existent possibles as the distinction between what is merely conceivable by God and what God actually conceives. As Nachtomy argues, this seems to run counter to divine omniscience (Nachtomy 2008, 252-253). 
Leibniz took the second option when he defined existence, first in terms of being sensed and then later in terms of harmony. The earlier definitions appeared in Fall $1667^{16}$ and again in 1671/2 (A VI.ii, 282-284 \& 487), just before he wrote the Confessio philosophi. The later definitions appear in the De summa rerum.

In the earlier attempts, Leibniz connected existence with being perceived in a way more often associated with Bishop Berkeley:

When I inquire more deeply into not only the nature of Extension, but also into that of existence generally, I seem to myself to have discovered in the end that to Exist is nothing other than to be Sensed - to be sensed however, if not by us, then at least by the Author of things [sentiri ab Autore rerum], to be sensed by whom is nothing other than to please him, or to be Harmonious. (1672; A VI.iii, 56 = partial translation from Adams 1994, 169)

This passage shows that Leibniz was offering something other than the extensional equivalence between existence and maximal harmoniousness that he would defend in his maturity, because there is no mention of maximality, and more importantly, because the passage concerns the "nature ... of existence generally," not the nature of whatever exists.

This is also apparent from context. It follows a criticism of Descartes's attempt to show that "[ $\mathrm{t}]$ he nature of body consists not in weight, hardness, colour, or the like, but simply in extension" (Descartes 1984-1991, I, 224). Leibniz rejected Descartes's conclusion without rejecting Descartes's ambition to know natures or essences. He claimed to have inquired more deeply and thoroughly, and to have discovered the true nature of existence. The dispute with

16 "Whatever can be sensed, is called being. And that is the most perfect definition of being" (A VI.i, 285). 
Descartes is about natures and how to discover them, not about the reason for the existence of something with a given nature. ${ }^{17}$

The 1672 passage on the nature of existence, considered above, contains at least three distinct theses, or three distinct though purportedly equivalent definitions: to exist is (1) to be sensed, (2) to please God, and (3) to be harmonious. Of these, (1) appears to be conceptually primary. The others are derived from it: (2) and (3) are restatements of (1) given the facts about God, who perceives all and responds appropriately. The slightly later attempts in the De summa rerum reject (1), promote (3) to conceptual priority, and treat (2) as an implication of (3) given the facts about God. That is, Leibniz comes to think that to exist is to be harmonious, and thereby to please God.

The first section of the De summa rerum, from three years later, December 1675, shows the insufficiency of (1) on its own: "Sensation is not the existence of things, because we declare that there exist things which are not sensed." Earlier in this passage, Leibniz noted that the definition also fails in the other direction, because we do sense things that do not exist. This is not quite a rejection of (1) as qualified by (2), however, because Leibniz must still hold that God perceives everything correctly. The rejection of (1) comes in the next sentence, as Leibniz goes on to explain sensation in terms of something more fundamental: "The coherence of sensation must itself spring from some cause. Existence, therefore, is the quality of the subject which brings it about that we have coherent sensations" (A VI.iii, $464=$ DSR 9). Leibniz rejects the

${ }^{17}$ Robert Adams $(1994,168)$ offers a competing interpretation of Leibniz's apparent definitions of existence. On his view, Leibniz sought to "exhibit the reason or cause that any existence would have," not to explain the nature of existence itself. However, Adams's argument for this interpretation is built on his reading of a 1686, post-Paris statement about existence. Adams's interpretation does apply to the post-Paris statements, which exhibit the reason or cause for any existence, but not to the Paris-period definitions, which attempt to exhibit the nature of existence itself. 
idea that existence is being sensed because sensation requires an explanation and, plausibly enough, whatever defines existence should not be explained by some further existent. ${ }^{18}$

The final version of Leibniz's Paris period definition of existence appeared three months later, in February 1676. According to this statement, harmony (3) explains why God is pleased with existents (2), and also why they may be sensed in the first place (1):

It seems there is . . some most perfect mind [Mentem], or God. This mind, like a soul, exists as a whole in the whole body of the world; the existence of things is due to this mind. It is the cause of itself. Existence is nothing other [Nihil aliud esse existentiam] than that which is the cause of consistent sensations.... To exist is nothing other [Existere nihil aliud esse] than to be harmonious; consistent sensations are the mark of existence. (A VI.iii, $474=$ DSR 25, translation emended to be more literal.)

The fact that sensation or being sensed is now deemed a mark of existence is further evidence that Leibniz is explaining what existence is, and not why certain things exist. Harmony makes for sensibility, but it just is existence.

Aside from its pantheistic overtones, Leibniz's analogy between God \& creation and soul \& body is striking because it leaves out the divine will. ${ }^{19}$ A more traditionally Christian statement, in which God is less closely tied to finite existents, would involve the divine will in

${ }^{18}$ Leibniz makes this point more clearly a decade later: “'existent' is what pleases something intelligent and powerful; but in this way existence itself is presupposed" (Generales inquisitiones de analysi notionum et veritatum, 1686; A VI.iv, 763 = P 65-66).

${ }^{19}$ I read "Mentem" either as a term for the intellect specifically, or else a general term for the mind that more readily refers to its intellectual capacities than to its volitional capacities. 
their origin. ${ }^{20}$ This absence is not accidental, because where Leibniz does adopt more conventional formulas for creation or conservation in the De summa rerum, he is quick to marginalize the will. Two months later, in April 1676, he wrote that "the mind will nonetheless be created by God, since it will exist and remain by the will of God, that is by the will of a good intellect. For to exist is nothing else but to be understood to be good" (A VI.iii, 512 = DSR 65-7, translation emended to be more literal). Leibniz mentions the will, but then immediately subordinates the will to the intellect and offers a version of the definition that highlights understanding, the distinctive act of the intellect.

Leibniz is right to marginalize the will, because each version of the definition so far has no place for the will as a capacity to create or initiate external action. If existence were something other than what God knows in knowing a harmonious possible, then the divine will could play a role in supplying or initiating this something. God would know harmony but will existence as a sort of reward for harmony. ${ }^{21}$ However, the will cannot reward a pleasantly harmonious possible with existence if existence just is being harmonious or pleasing to Godthe work is already finished when the will enters the scene. At most, willing-the-existence-of-apossible is just approving of what exists, or disapproving, if something unharmonious like sin is part of a harmonious whole. ${ }^{22}$

${ }^{20}$ Martin Luther understood creation as a purely sovereign act of love (Schwanke 2014), and Aquinas writes, "We must hold that the will of God is the cause of things; and that He acts by the will, and not, as some have supposed, by a necessity of His nature" (Summa Theologiae, I.19.4; Aquinas 1920).

${ }^{21}$ Of course, God would still know what exists, but this knowledge would be founded on God's knowledge of what God wills (see G II, $44=$ AG 74).

${ }^{22}$ As noted above, Rateau (2014, 169; see also 2019, 65-67) also highlights this marginalization of the will during the Paris Period, but connects it only to Leibniz's early theodicy, not to the 
This fits with Leibniz's definition of the will in the Confessio philosophi: "To will in favor of something is to be delighted by its existence" (A VI.iii, $127=$ CP 55). Nicholas Steno, who conversed with Leibniz about the Confessio philosophi and annotated Leibniz's manuscript, objected that this definition reduces the will to a capacity for pleasure and pain. Leibniz retorted: if Steno "understood the nature of the will, he would admit that it consists in this" (A VI.iii, 127 $=\mathrm{CP} 54-5) .{ }^{23}$ Restricted to pleasure and pain, and perhaps to cooperation with the intellect in judgments concerning goodness, the divine will figures in the account of finite existence only after the fact, as the capacity affected by harmony. ${ }^{24}$

We have so far encountered several overlapping attempts to define existence. In the earliest, to exist is just to be sensed by God and to please God (1672). Leibniz rejected this formula in the De summa rerum, because being sensible and pleasing God may both be explained by something more fundamental (December 1675). This insight produced the simplest

definitions of existence that seem to preclude any creative act: "Not only does the will come after the judgement of the understanding, following the intellectualist thesis, but it seems to come, so to speak, after the power and the creative act itself, as a pleasure taken in the contemplation of what has been brought into existence" (my translation).

${ }^{23}$ Steno's objections and Leibniz's replies appear in the margin of the second Confessio philosophi manuscript and they are translated in the Yale Leibniz volume. Working from Otto Saame and Yvon Belaval's editions, Sleigh (CP xxiii-xxiv) dates the replies to Steno to late 1677 or early 1678, well after Leibniz left Paris. Given their late date, nothing in my argument about Leibniz's Paris metaphysics should depend on the replies. Also, we should expect some replies that do not cohere with the positions Leibniz expressed in Paris, such as commitments to a causally efficacious will at A VI.iii, $122 \& 124$ (= CP 43 \& 47).

24 This does not make the divine will passive before created things if there are no created things distinct from the divine intellect. One might also object that God does not have sensations, but Leibniz has already mentioned that God senses in the 1672 definition: "sentiri ab Autore rerum." 
definition: to exist is to be harmonious (February 1676). Leibniz then reincorporated God: for something to exist is for God to understand its goodness or harmony (April 1676). The simplest definition straightforwardly explains the others, given the existence of God, and it is the only one that applies to God without circularity.

These early definitions of existence allowed Leibniz to distinguish between the existent and the non-existent possibles without giving God's will a causally efficacious role in creation, and so without giving God moral responsibility for sin. The distinction is internal to God's intellect, and this is exactly what Leibniz needed to uphold what he had claimed in his theodicy several years before, both that there are non-existent possibles and that the existent possibles, like any other possibles, have their being as objects of God's intellect. I do not claim that Leibniz adopted these definitions in order to fill a gap in his theodicy, or that he developed the theodicy to fit the definitions. I only claim that they are mutually supportive positions, and that their mutual support is a reason to adopt a strictly intellectualist and hence necessitarian interpretation of the Confessio philosophi and the De summa rerum.

\subsection{Necessitarianism and the Definition of Existence: Are Non-existent Possibles Even Possible?}

Unfortunately for Leibniz, his definition of existence completely undermines his commitment to non-existent possibles. As argued already in section 1, the distinction between per se and hypothetical necessity explains the contingency of finite existents only if they are really distinct from God—but defining existence as harmoniousness further precludes any real distinction between God's intellect and its harmonious objects. That is, Leibniz's definition of existence 
contributes to a sort of monism, which in turn reduces the range of available anti-necessitarian strategies. $^{25}$

The definition also implies strong necessitarianism on its own via this short, original argument:

1. It is necessary for each possible to be as it is. (That is, a possible could not be different without being a different possible, or a different way for things to be.)

2. If it is necessary for each possible to be as it is, then each possible is necessarily harmonious if harmonious.

3. So each possible is necessarily harmonious if harmonious.

4. But existence just is harmoniousness.

Therefore, each possible necessarily exists if it exists.

To make matters worse, non-existent possibilia are necessarily non-existent, because they are necessarily non-harmonious and non-harmoniousness just is non-existence.

To make matters even worse, it seems there are no non-existent possibles: if a nonexistent possible had existed, it would have existed necessarily, because - as the argument shows - possibles exist necessarily if they exist at all. But if something is possibly necessary, it already does exist and is not merely possible. This assumes the modal axiom, $(\diamond \alpha \rightarrow \alpha)$, which Leibniz endorsed enthusiastically in December 1676: "We have a splendid theorem, which is the pinnacle of modal theory and by which one moves in a wonderful way from potentiality to act: If a necessary being is possible, it follows that it exists actually, or, that such a being is actually

25 There is a rich literature on whether and to what extent Leibniz was committed to monism in this early period. See Kulstad 2000 \& 2005, Mercer 2000, and Lærke 2009b \& 2013. The definition produces other difficult results: if sins are non-harmonious parts of a harmonious whole, are they also non-existent parts of an existent whole? 
found in the universe" (A VI.iii, 583 = DSR 107). Unless this is a new commitment, accepted only after leaving Paris, the Leibniz who met Spinoza in November 1676 was committed to the idea that every possible is necessarily actual. ${ }^{26}$

This problem is more serious than the well-known necessitarian problem from Leibniz's later work. Here it is:

1. Necessarily, God exists.

2. Necessarily, if God exists then God creates the best possible world.

3. Whatever world is best, $w_{b}$, is so necessarily.

Therefore, $w_{b}$ exists necessarily. ${ }^{27}$

The later Leibniz sometimes denied the second premise by claiming that God's power extends beyond God's wisdom. Every internally coherent world is per se creatable or possible; the best world is only hypothetically necessary, assuming God's wisdom (Gr 478-9 = SLT 96). Elsewhere he denies the third premise by defining possibility in terms of infinite analysis: $w_{b}$ is only contingently best because proving its superiority would require a comparison with infinitely many other worlds (A VI.iv, 1517-8= MP 98-9).

Even if his revisionary theories of modality were to fail, the later Leibniz could at least defend counterpossibles such as, "if God were to will some world other than $w_{b}$, that world would exist." Not even this turns out true on the earlier view, because it may be rephrased as: "if God were to will a non-harmonious possible, that possible would be harmonious." God acting badly is more conceivable than God making a contradiction true.

${ }^{26}$ Leibniz did note this argument several years later: "the reason why these exist rather than those should not be sought in their definition (for then nonexistence would imply a contradiction, and those others would not be possible, contrary to our hypothesis)" (A VI.iv, $1445=$ AG, 19). 27 This formulation is from Sleigh's presentation at Skidmore College in June 2010. 
As noted already, the per se necessity theory of modality does not help the early Leibniz to avoid necessitarianism, because the possibles in question are not really distinct from God, and so share in God's per se necessity. ${ }^{28}$ We may now add that the existence (or harmoniousness) of a non-harmonious possible would involve a contradiction in the possible itself, not further up the causal chain in God. Sleigh cannot be right that Leibniz's early commitment to necessitarianism was only a matter of terminological poverty, resolved when Leibniz made the distinction between per se and hypothetical necessity explicit.

We should take the definition of existence in the De summa rerum seriously, because Leibniz returned to it and improved it over the course of several years, and because it fits well with Leibniz's theodicy of the same period. But if taken seriously, the definition commits Leibniz to a strong form of necessitarianism, unresponsive to the usual Leibnizian cures.

\section{3. (Dis)continuity after Paris}

I have argued so far on two levels: one concerns Leibniz's avowed commitments, and the other concerns his unwanted and perhaps unintentional commitments. On the first level, I argued that Leibniz left the will without causal power for the sake of theodicy, and that he distinguished between existent and non-existent possibles without appeal to a causally efficacious will, by defining existence in terms of harmony. He seems to have made these moves intentionally and explicitly, as evidenced by the statements themselves, and also by the way in which the moves fit together. The best argument to the contrary is that Leibniz could not have held positions that imply strong necessitarianism, because he made efforts already in the Confessio philosophi to avoid necessitarianism. Sleigh's argument against the necessitarian reading of the Confessio

28 The infinite analysis theory may help; perhaps possibles are contingently harmonious because infinitely complex. However, Leibniz developed this theory around 1686 (A VI.iv, 760-1 = P, 63-4), well after the post-Paris developments described here. 
philosophi rests on these efforts, and on the fact that Leibniz's post-Paris work on per se necessity is clearly not necessitarian $(1996,492$; CP xxxv).

The second line of argument concerns Leibniz's unintentional commitments and provides an alternative to Sleigh's interpretation. We may follow the evidence for strong necessitarianism in the early Leibniz precisely because the slightly more mature Leibniz rapidly altered his theodicy and metaphysics in ways that remove this evidence and thereby avoid strong necessitarianism. This discontinuity in Leibniz's development is much more puzzling if the earlier positions never did imply strong necessitarianism.

The discontinuity at least coincided with Leibniz's encounters with Spinoza's metaphysics. The first encounter with Spinoza took place in 1670-1, when Leibniz briefly corresponded with Spinoza and read the Tractatus Theologico-politicus, a work he revisited in late 1675 and 1676 - but the first intensive encounter with Spinoza's metaphysics and theodicy (that is, his view of the divine will and its relation to the good) likely took place no earlier than February 1676, when Tschirnhaus may have received permission to share ideas from the Ethics with Leibniz (A VI.iii, 380). Before meeting Spinoza face to face on November 18, 1676, Leibniz also read and annotated some of Spinoza's letters (A VI.iii, 275-82, 364-71, and 3805). Finally, he received Spinoza's Opera posthuma immediately after its publication in 1677, and produced extensive notes on the Ethics beginning in early 1678 (A VI.iv, 1705-77). ${ }^{29}$ Spinoza embraced the implications that troubled Leibniz, and this seems to have helped Leibniz to see the trouble with his own theodicy and metaphysics. ${ }^{30}$

\subsection{Existence after Paris}

${ }^{29}$ See also the helpful summaries of Leibniz's early encounters with Spinoza's thought in Lærke 2009a, 206-9 and Antognazza 2009, $121 \& 167-9$.

${ }^{30}$ Rateau makes the same suggestion: "[...] in opposing Spinoza, Leibniz is struggling against a tendency and inclination inherent in his own philosophy" $(2019,91)$. 
In November 1676, while crossing the English Channel to visit Spinoza, Leibniz wrote that existence is unanalyzable or undefinable: "Perfections, or simple forms, or absolute positive properties, are indefinable or unanalyzable ... existence [existentia] is one of the number of perfections, or absolute positive qualities" (A VI.iii, 575-6= DSR 97). It is hard to attribute this passage to the author of the rest of the De summa rerum, which contains so many analyses of existence. The contrast is explained, in part, by Leibniz's effort to improve the ontological argument, which required that existence be a simple, positive property compossible with every other such property. This argument was one topic of conversation between Leibniz and Spinoza, and Leibniz's notes about it have an experimental quality. Another passage, from 1677, suggests that Leibniz's view of existence remained in flux through the following year:

It may be doubted very much whether existence [existentia] is a perfection, or a degree of reality ... Therefore, existence [existentia] will be the excess of one thing's degree of reality over that of another opposing thing. In other words, that which is more perfect than all things incompatible with it exists [existit] and likewise, what exists [existit] is more perfect than other things. (A VI.iv, 1354)

This passage about finite existents appears to contradict the previous, which more directly concerns God's existence. For our purposes, it is enough that neither passage offers a definition. He first states that existence will be something, but then immediately paraphrases in terms of what exists. He is stating a fact about what exists, not a definition of existence itself.

Leibniz continued to make statements about existence well into his career, but after 1677, he no longer defined existence in terms of harmony. Whereas the Paris Period statements seem to specify the nature or essence of existence, the later definitions, if they are definitions at all, state a fact about what all and only the existent possibles have in common. For example, as Leibniz wrote sometime between 1687 and 1696, "The existing thing [Existens] is compossible 
with the most perfect" (A VI.iv, 867). In this passage, Leibniz associates what exists [existens], and not existence itself [existentia], with perfection. ${ }^{31}$ Leibniz even asserts in 1686 that a cause may be given for existence [existentiae] but that "existent [Existens]" may be defined, thereby at least implying that existence itself is not up for definition (A VI.iv, $744=\mathrm{P}, 51) .{ }^{32}$ This undercuts a key premise - that existence just is harmoniousness — of the argument for strong necessitarianism. Existence coincides with maximal perfection or harmony not because existence is that feature, but because God decides to create possibles with that feature. Even if this further fact about divine choice is necessarily true, it is at least the extra premise that makes Leibniz's revisionary modal theories relevant.

Leibniz sometimes makes this point about existing things without mentioning God or creation. For example:

Existing [Existens] can no more be defined than essence [Ens] or what is purely positive; however, so that the notion may be more clearly exhibited to us, it should be known that every possible exists [extiturum esse] if it can, but since not all possibles may exist, one impeding the other, those exist which are more perfect. (1685; A VI.iv, 626)

Existing cannot be defined; nevertheless, we can know what all and only the existent possibles have in common, and even know why they have this in common. One way to explain why this is true features a causally efficacious divine will, and another features the competition or struggle among possibles, each of which will exist if it is not impeded by others of greater perfection.

${ }^{31}$ For further examples from the 1680s, see A VI.iv, $568 \& 875$.

32 Of course, there is an exception. Leibniz claims that "existence is distinct sensibility" in 16901694 (VE, 2250) in a passage that highlights a symmetry with essence, defined as distinct thinkability. 
Leibniz offers this sort of God-free explanation for why only certain possibles exist in 1677, in a work entitled, surprisingly, Elementa verae pietatis, sive de amore Dei super omnia (see also, from February 1676, A VI.iii, 472 = DSR 20-1). Having just offered a new and causally efficacious account of God's will, Leibniz answers an imagined interlocutor who argues that if God's will is the cause of everything, then it is the cause of the goodness of things. Leibniz replies that God's will is only the cause of the existence of things, not of their essences, which are contained in God's intellect. These essences, each in some way harmonious or good, may be said to have a "propensity to exist [ad existendum propensionem]" or a "strength for existing [existendi vis]" (crossed-out in A) proportionate to their degree of harmony or reality (A VI.iv, 1361-3 = SLT 195).

This is Leibniz's theory of the "striving possibles" and it appears occasionally in Leibniz's mature work (for example, from November 1697, G VII, $303=$ AG 150). The view seems to compete with Leibniz's mature account of the divine will as described in section 3.2 below. Do the possibles themselves push through to existence, impeded only by each other, or does the divine will have an indispensable role to play once one group of possibles emerges as best suited for existence? The second interpretation seems better, because the first contradicts Leibniz's description of the will's role in creation expressed only lines above in the Elementa verae pietatis and throughout the mature work. ${ }^{33}$

Nevertheless, the more literal interpretation should not be dismissed out of hand, especially given its similarity to Leibniz's only recently abandoned definitions of existence. According to the earlier definitions, existence just is harmoniousness, a feature of some

${ }^{33}$ David Blumenfeld (1994) reads the "striving possibles" account figuratively and Christopher Shields (1986) reads it literally, though in a way that preserves a role for the divine will in creation. The present discussion is not intended to resolve all interpretive issues around Leibniz's talk of striving possibles, but only to point out a telling continuity between the early views and this more peculiar feature of his mature view. 
possibles. According to the literal interpretation of the "striving possibles" theory, some possibles attain existence simply in virtue of having more perfection than other, competing possibles. If the Paris Period definition complemented Leibniz's early theodicy, in which the divine will remains innocent of sin through its lack of involvement in creation, perhaps the "striving possibles" theory complements the new theodicy, in which the will remains innocent through its lack of involvement in determining which possibles will be created?

Recall that Leibniz's aim in the Confessio philosophi was to show that God is not the author of sin. Substituting in Leibniz's definition of "author," this expands to the claim that God is not the ground of sin by God's will. Although Leibniz does not define "ground [ratio]" in the Confessio philosophi, he does treat it as a more precise substitute for "cause." This, together with the lexical definitions of ratio, suggests a pair of necessary and only jointly sufficient conditions for God to be the author of sin: the divine will would have to both (a) cause sin to exist and (b) make sin intelligible. The early theodicy denies both by removing the will entirely, but Leibniz only needs to deny one of these in order to show that God is not the author of sin. The "striving possibles" metaphor highlights the way in which Leibniz's new theodicy contradicts only the latter.

In Leibniz's new view, God does cause sin to exist by willing the existence of creatures that $\sin$ (thereby meeting condition $a$ ), but as in the early theodicy, the possibles themselvesand not the will—make sin intelligible (thereby not meeting condition $b$ ). God does will to create, but only according to the prompt of the divine intellect, or of the possibles themselves. Indeed, just before the first appearance of the striving possibles, Leibniz wrote, "Even God discovers that some things are good, or better than others. For God is endowed with will; the will is under the rule of the good" (A VI.iv, 1361 = SLT 193).

\subsection{The Will after Paris}


It should be apparent, by now, that Leibniz's effort to avoid strong necessitarianism was more than a matter of terminological or ontological expansion, because it was bound up with his effort to preserve the insight that the divine intellect explains what exists while avoiding that insight's implications. The same pattern emerges in Leibniz's treatment of the divine will just after leaving Paris. The earliest crisp statement of the will's productive role in creation comes already in the second half of October 1676, when Leibniz had just left Paris for London and would shortly leave London to visit Spinoza:

This should be explained, that the world could not have been made other than it is, for God cannot but operate in the most perfect way. Since he is most wise, he chooses the best. It is far from true that everything follows from God's nature without any intervention of the will. (Marginalia to a copy of Letter 3 from Spinoza to Oldenburg; A VI.iii, 364)

Once again, it is difficult to attribute this emphatic note to the author of the Paris works. It is surely relevant to Leibniz's tone that the note was an immediate and personal reaction to Spinoza's claim in the letter to Oldenburg: "I hold that all things follow from the nature of God by an ineluctable necessity [inevitabili necessitate]" (A VI.iii, 364).

Leibniz, at this point, is still willing to agree that the world could not have been made differently. He baulks less at Spinoza's necessitate than at his inevitabili. That is, Leibniz is still willing to accept some form of necessitarianism, but not of the type favored by Spinoza and implied by Leibniz's own theodicy and definition of existence, in which everything follows directly from God's nature. This world may exist necessarily, but that necessity has two grounds: the maximal perfection of certain possibles and God's goodness, neither of which rule out equally creatable though less perfect alternatives.

By 1681 at the latest, Leibniz had settled on his mature view that the divine will should not even be called necessary, let alone inevitable (A VI.iv, 1389), but in late 1677 he was still 
working out the details of his new account. For example, in the Confessio philosophi he had defined the will as a capacity for pleasure or pain (A VI.iii, $127=\mathrm{CP} 55$ ), but in Elementa verae pietatis, he offers a far more robust definition of the will: "the will is the thinking about good and evil together with the endeavor to act" (A VI.iv, 1361 = SLT 193). The divine will has gained a causally efficacious (though perhaps still necessitated) role without losing the more contemplative task assigned to it in the Confessio philosophi. ${ }^{34}$

According to the new account, developed at least in its fundamentals very soon after Leibniz left Paris, existence is undefinable, but nevertheless coextensive with maximal harmony. The will is a necessary part of Leibniz's new account of why that coextension holds true: it is true because God wills — whether necessarily or not—-that these possibles exist and not others. As in the earlier work, however, the possibles themselves play the primary explanatory role through their "struggle," or the process by which a most perfect group of possibles moves the will to create. Despite the discontinuities Leibniz introduced to avoid being a self-made Spinozist and necessitarian, the new account inherits a core aspect of the early theodicy, the explanatory priority of the possibles: their degree of harmony or perfection explains the existence of this world, whether by just being this existence or by prompting the will to create. ${ }^{35}$

Sleigh and Lærke, despite their disagreements, both explain Leibniz's escape from necessitarianism in ways that do not capture this deeper continuity. For Sleigh, Leibniz in Paris already rejected necessitarianism for a reason he could almost articulate, the distinction between hypothetical and per se necessity_-but, as I argue, that distinction only applies after Leibniz's more robust account of the will and less robust account of existence open a real distinction

34 Andreas Blank 2016, 40-2 argues that around 1678 Leibniz simply identifies beliefs or judgments with inclinations, or potentially causal volitional acts.

${ }^{35}$ For a later (1689) summary of this account, including the striking coinage, "the about-to-beexisting-ness of essences [Existiturientia Essentiarum]," see A VI.iv, 1634-1635. 
between God and created things. Sleigh's interpretation cannot explain why the modal distinction's full articulation coincided with these abrupt shifts on will and existence.

Lærke can make sense of Leibniz's Paris Period definitions of existence as a sort of ontological collapse, in which existence and possibility share exactly the same ground: God's act of conceiving. Necessitarianism follows because the non-existent possibles are mere abstractions, not real contents of God's intellect. To escape, Leibniz only needed to explain that the non-existent possibles are objects of God's intellect, not just potential objects of God's intellect (Lærke 2007, 8). There is more to the story, however, because the Paris Period collapse of existence and possibility solved a problem in Leibniz's early theodicy, and so the subsequent ontological expansion had to occur in tandem with Leibniz's effort to resolve that same problem.

Rateau (2019, 93-107) does capture this deeper continuity, insofar as the striving possibles doctrine opens a way to strengthen the divine will — thereby blocking the first path to strong necessitarianism - while still appealing to God's intellect and the possibles themselves to explain the balance of sin and imperfection in this world: "A possible that tends to existence is at the same time an object that is willed in proportion to its perfection" (107, emphasis original). However, Rateau misses the full extent of the discontinuity in Leibniz's metaphysics. The dynamic view of the possibles is a stronger version of Leibniz's claim that possibles are what can be conceived without contradiction (95), but it is also a weaker version of his claim that existence just is harmoniousness - and Leibniz must weaken this claim to block the second path to strong necessitarianism.

\section{Conclusion}

The threat of necessitarianism in Leibniz's mature philosophy comes from necessities about God's will and about the collection of all possible worlds. Leibniz had room to maneuver; he could weaken these necessities by offering revisionary theories of modality. In contrast, the early threat of necessitarianism derived from a stripped-down ontology in which the only relevant 
items are God's intellect (as the source of finite beings) and the harmonies it grasps (as the very existence of finite beings). This ontology elegantly reconciled God's innocence of sin with the intelligibility of creation and its dependence on God-but it also committed Leibniz to a strong, almost Spinozistic, necessitarianism. After encountering Spinoza, Leibniz rapidly and yet carefully emended his philosophy, to avoid this strong necessitarianism without sacrificing the central theodicean insights and motivations of the Paris Period.

Leibniz's early commitment to strong necessitarianism and his rapid escape were both attempts to reconcile perfect divine harmony and imperfect creaturely harmony. The complex terminological and ontological developments come into focus only when viewed through this theodicean lens.

\section{Bibliography}

Robert Merrihew Adams. 1977. "Leibniz’s Theories of Contingency.” Rice Institute PamphletRice University Studies: Essays on the Philosophy of Leibniz 63, no. 4, edited by Mark Kulstad, 1-41. Houston: 1977.

—. 1994. Leibniz: Determinist, Idealist, Theist. Oxford: Oxford University Press.

Maria Rosa Antognazza. 2009. Leibniz: An Intellectual Biography. Cambridge: Cambridge University Press.

Thomas Aquinas. 1920. Summa Theologiae. Translated by The Fathers of the English Dominican Province. Second and Revised. Online Edition Copyright 2008 by Kevin Knight. url: www.newadvent.org/summa/.

Andreas Blank. 2016. "Striving Possibles and Leibniz's Cognitivist Theory of Volition.” Journal of Early Modern Studies 5: 29-52.

David Blumenfeld. 1994. "Leibniz's Theory of the Striving Possibles.” In Gottfried Wilhelm Leibniz: Critical Assessments, Volume 2, edited by R. S. Woolhouse, 1-13. London: Routledge. 
J. A. Cover and John O'Leary-Hawthorne. 1999. Substance and Individuation in Leibniz. Cambridge: Cambridge University Press.

René Descartes. 1984-1991. The Philosophical Writings of Descartes. Edited and translated by John Cottingham et al. 3 vols. Cambridge: Cambridge University Press.

Ursula Goldenbaum. 2007. “Why Shouldn't Leibniz Have Studied Spinoza? The Rise of the Claim of Continuity in Leibniz' Philosophy out of the Ideological Rejection of Spinoza's Impact on Leibniz." The Leibniz Review 17: 107-138.

Michael V. Griffin. 2013. Leibniz, God and Necessity. Cambridge: Cambridge University Press. Mark A. Kulstad. 2000. "Pantheism, Harmony, Unity and Multiplicity: A Radical Suggestion of Leibniz's De Summa Rerum." In Unità e molteplicità nel pensiero filosofico e scientifico di Leibniz, Lessico Intellettuale Europeo, Volume 84, edited by A. Lamarra and R. Palaia, 97-105. Florence: Olschki.

- 2005. "The One and the Many and Kinds of Distinctness: The Possibility of Monism or Pantheism in the Young Leibniz." In Leibniz: Nature and Freedom, edited by Donald Rutherford and Jan A. Cover, 20-43. New York: New York University Press.

Jeffrey McDonough. 2007. "Leibniz: Creation and Conservation and Concurrence." The Leibniz Review 17: 31-60.

Mogens Lærke. 2007. “Quod non omnia possibilia ad existentiam perveniant: Leibniz’s ontology of possibility, 1669-1678." The Leibniz Review 17: 1-30.

—. 2008a. Leibniz Lecteur de Spinoza. Travaux de Philosophie 16. Paris: Honoré Champion Éditeur.

—. 2008b. "Response to Ohad Nachtomy on Possibilia in Leibniz, 1672-1676." The Leibniz Review 18: 259-266.

—. 2009a. "De origine rerum ex formis (April 1676): A Quasi-Spinozistic Parallelism in De summa rerum." In The Young Leibniz, Studia Leibnitiana Sonderheft 35, edited by David Snyder, Mark Kulstad, and Mogens Lærke, 203-19. Franz Steiner Verlag. 
—. 2009b. "Monism, Separability and Real Distinction in the Young Leibniz." The Leibniz Review 19: 1-28.

—. 2013. “Leibniz's Encounter with Spinoza’s Monism, October 1675 to February 1678." In The Oxford Handbook of Spinoza, Oxford Handbooks Online, edited by Michael Della Rocca. Oxford University Press. URL = www.oxfordhandbooks.com/view/10.1093/oxfordhb/9780195335828.001.0001/oxfordhb $-9780195335828-e-013$.

Gottfried Wilhelm Leibniz. 1857. Nouvelles lettres et opuscules inédits de Leibniz. Edited by Foucher de Careil. Paris: Auguste Durand.

—. 1875-90. Philosophische Schriften. Edited by C. I. Gerhardt. 7 vols. Berlin: Weidman.

-. 1923-. Sämtliche Schriften und Briefe. Darmstadt and Berlin: Berlin Academy.

—. 1948. Textes Inédits d'après les Manuscrits de la Bibliothèque Provinciale de Hanovre. Edited by Gaston Grua. 2 vols. Berlin: Presses Universitaires de France.

—. 1961 (revised edition in 1970). G. W. Leibniz, "Confessio philosophi”-La Profession de foi du philosophe. Edited and translated by Yvon Belaval. Paris: Vrin.

—. 1966. Logical Papers. Edited and translated by G. H. R. Parkinson. Oxford: Clarendon Press.

—. 1967 (reprinted and lightly revised in 1994). G. W. Leibniz: “Confessio philosophi.” Edited and translated by Otto Saame. Frankfurt am Main: Klostermann.

—. 1973. Leibniz: Philosophical Writings. Edited by G. H. R. Parkinson. Translated by Mary Morris and G. H. R. Parkinson. London: J M Dent \& Sons Ltd.

—. 1985. Leibniz: Monadology and other Philosophical Essays. Edited by Paul Schrecker. New York, Macmillan Publishing Co.

—. 1989. Philosophical Essays. Edited and translated by Roger Ariew and Daniel Garber. Hackett.

—. 1990. Theodicy. Edited and translated by E. M. Huggard. Chicago: Open Court.

- 1992. De summa rerum: Metaphysical Papers, 1675-1676. Edited and translated by G. H. R. Parkinson. The Yale Leibniz. New Haven and London: Yale University Press. 
-. 2005. Confessio philosophi: Papers Concerning the Problem of Evil, 1671-1678. Edited and translated by Robert C. Sleigh, Jr. The Yale Leibniz. New Haven and London: Yale University Press.

—. 2006. The Shorter Leibniz Texts: A Collection of New Translations. Edited and translated by Lloyd Strickland. London: continuum.

—. 2018. Advance copy of series VI, volume v from Sämtliche Schriften und Briefe. Darmstadt and Berlin: Berlin Academy.

Samuel Levey. 2013 "Review of Michael Griffin, Leibniz, God and Necessity.” The Leibniz Review 23: 171-185.

Martin Lin. 2011. "Rationalism and Necessitarianism.” Nous 46: 418-48.

Christia Mercer. 2000. "God as Both the Unity and Multiplicity in the World." In Unità e molteplicità nel pensiero filosofico e scientifico di Leibniz, Lessico Intellettuale Europeo, Volume 84, edited by A. Lamarra and R. Palaia, 71-95. Florence: Olschki.

—. 2001. Leibniz's Metaphysics: Its Origins and Development. Cambridge: Cambridge University Press.

Ohad Nachtomy. 2007. Possibility, Agency, and Individuality in Leibniz's Metaphysics, The New Synthese Historical Library 61. The Netherlands: Springer.

—. 2008. "Remarks on Possibilia in Leibniz, 1672-1676: Quod non omnia possibilia ad intelligentiam perveniant?" The Leibniz Review 18: 249-257.

Samuel Newlands. 2010. "The Harmony of Spinoza and Leibniz." Philosophy and Phenomenological Research 81: 64-104.

—. 2013. "Leibniz and the Ground of Possibility." Philosophical Review 122: 155-187.

Paul Rateau. 2014. 'La nécessité de l'optimum dans la Confessio philosophi: un nécessitarisme leibnizien?” In Spinoza/Leibniz: Recontres, controverses, réceptions, edited by Raphaële Andrault, Mogens Lærke, and Pierre-François Moreau, 161-173. Paris: Presses de l’Université Paris-Sorbonne.

—. 2019. Leibniz on the Problem of Evil. Oxford: Oxford University Press. 
André Robinet. 1994. G. W. Leibniz: Le meilleur des mondes par la balance de l'Europe. Paris: Presses Universitaires de France.

Johannes Schwanke. 2014. "Luther's Theology of Creation.” In The Oxford Handbook of Martin Luther's Theology, edited by Robert Kolb, Irene Dingel, and L'ubomír Batka. Oxford: Oxford University Press.

Christopher Shields. 1986. “Leibniz's Doctrine of the Striving Possibles.” Journal of the History of Philosophy 24: 343-357.

Robert C. Sleigh. 1996. “Leibniz’s First Theodicy.” Philosophical Perspectives 10: 481-99. Lloyd Strickland. 2006. Leibniz Reinterpreted. London: Continuum. 